\title{
PENGARUH PEMBERIAN TABLET Fe DENGAN PENAMBAHAN SARI KACANG HIJAU DALAM PENINGKATAN KADAR Hb IBU HAMIL
}

\author{
THE EFFECT OF GIVING IRON TABLET AND GREEN BEAN \\ EKSTRACT ON HEMOGLOBIN LEVELS IN PREGNANT WOMEN
}

\author{
Wenny Indah Purnama Eka Sari, Almaini, Dahlia \\ Poltekkes Kemenkes Bengkulu \\ Korespondensi : wennyindah187@gmail.com
}

\begin{abstract}
Nutrition is one of the factors that influence the outcome of a pregnancy. Inadequate fulfillment of nutritional needs during pregnancy can cause anemia. The effect of anemia in pregnancy can increase the risk of preterm birth and fetal growth disorders. To overcome anemia, increasing food intake can be pursued by consuming foods that contain high nutrients and increasing iron absorption. One of the foods rich in iron is green vegetables and nuts. One type of nuts that contain high iron is green beans (Phaseolus Radiatus L). This research is quasi experimental with simple random sampling, subject is divided into two groups, intervention and control. The Intervention group of giving iron tablets and green bean ekstract for 7 days, and the control group of giving just iron tablet. Statistical test using Wilcoxon test with $p$ value $p=0,000$ showed differences level haemoglobin between intervention group and control group. The results showed that there was an effect of giving iron tablet green bean ekstract to an increase level haemoglobin in pregnant women third semester on district Puskesmas Nanti Agung Kepahiang Region 2019. The conclusion was giving tablet iron and green bean ekstract affect to an increase increase level haemoglobin in pregnant women third semester.
\end{abstract}

\section{Keywords: Green Bean, Iron Tablet, Level Haemoglobin}

\begin{abstract}
ABSTRAK
Nutrisi menjadi salah satu faktor yang ikut berpengaruh hasil akhir suatu kehamilan. Pemenuhan kebutuhan gizi selama kehamilan yang tidak tercukupi, dapat menyebabkan anemia. Pengaruh anemia dalam kehamilan dapat meningkatkan risiko kelahiran prematur dan gangguan pertumbuhan janin. Untuk menanggulangi anemia, peningkatan asupan makanan dapat diupayakan dengan mengonsumsi bahan makanan yang mengandung zat gizi tinggi dan meningkatkan absorpsi besi. Salah satu bahan makanan yang kaya zat besi adalah sayuran berwarna hijau serta kacang-kacangan. Salah satu jenis kacang-kacangan yang mengandung zat besi tinggi adalah kacang hijau (Phaseolus Radiatus $L$ ). Penelitian ini bersifat quasi eksperimental dengan dengan jumlah sampel 36 orang ibu hamil trimester III dengan teknik pengambilan sampel simple random sampling dibagi dua kelompok, kelompok perlakukan dan kontrol. Kelompok perlakuan di berikan tablet Fe dengan penambahan sari kacang hijau selama 7 hari, sedangkan kelompok kontrol di berikan tablet Fe saja. Pengujian statistik menggunakan uji wilcoxon diperoleh nilai $\mathrm{p}=0.000$ menunjukan ada perbedaan kadar hemoglobin pada kelompok perlakukan dan kelompok Kontrol. Hasil penelitian menunjukan ada pengaruh pemberian tablet $\mathrm{Fe}$ dengan penambahan sari kacang hijau dalam peningkatan kadar $\mathrm{Hb}$ pada ibu hamil di Wilayah Kerja Puskesmas Nanti Agung Kabupaten Kepahiang Tahun 2019. Simpulan
\end{abstract}


penelitian ini adalah pemberian tablet Fe dengan penambahan sari kacang hijau efektif meningkatkan kadar Hb pada ibu hamil TM III.

\section{Kata Kunci: Kacang Hijau, Kadar Hb, Tablet Fe}

\section{PENDAHULUAN}

Program Sustainable Development Goals (SDGs) merupakan program yang disusun oleh Perserikatan Bangsa Bangsa (PBB) menggantikan program sebelumnya, yaitu Millennium Development Goals (MDGs). Tujuan dari SDGs salah satunya menjamin kehidupan sehat melalui penurunan Angka Kematian Ibu (AKI) pada tahun 2030 menjadi 70 per 100.000 kelahiran hidup (Kemenkes, 2019).

Berdasarkan laporan World Development Indicators (2016) didapati $40 \%$ ibu hamil mengalami anemia di seluruh dunia. Anemia di Indonesia masih tinggi jika dibandingkan dengan negaranegara tetangga. Jumlah anemia pada ibu hamil di Indonesia yaitu sebanyak 42\%, sedangkan negara tetangga seperti Malaysia hanya 37\%, Singapura 32\%, Filipina 30\%, dan negara Brunei hanya $27 \%$ ibu hamil yang menderita anemia (IBRD, 2019).

Hasil Riset Kesehatan Dasar (Riskesdas) tahun 2018 menyatakan bahwa, di Indonesia sebesar 48,9\% ibu hamil mengalami anemia. Sebanyak 84,6\% anemia pada ibu hamil terjadi pada kelompok umur 15-24 tahun (Kemenkes, 2019).

Laporan Program Gizi Masyarakat Dinas Kesehatan Provinsi Bengkulu tahun 2018 menyebutkan bahwa, angka kejadian anemia pada ibu hamil yang tersebar di seluruh Kabupaten yang ada di Provinsi Bengkulu berjumlah $4.980 \quad(18 \%)$. Kabupaten Kepahiang merupakan Kabupaten dengan persentase ibu hamil dengan anemia tertinggi di Provinsi Bengkulu dengan jumlah 413 orang ibu hamil atau 29,8\%. Berdasarkan laporan Kesga Dinas Kesehatan Kabupaten Kepahiang, ibu hamil yang menderita anemia dan Puskesmas Nanti Agung mengalami peningkatan kejadian anemia pada ibu hamil di tahun 2019 yaitu sebanyak $35,5 \%$.

Kehamilan merupakan permulaan suatu kehidupan baru suatu periode pertumbuhan. Kondisi kesehatan di masa lampau sekaligus keadaan kesehatan ibu saat ini merupakan landasan suatu kehidupan baru. Nutrisi menjadi satu faktor yang ikut berpengaruh hasil akhir suatu kehamilan. Pemenuhan kebutuhan gizi selama kehamilan yang tidak tercukupi, dapat menyebabkan plasenta sebagai media 
sumber nutrisi tidak mampu menyediakan makanan yang cukup bagi janin. Hal ini dapat menimbulkan berbagai komplikasi yang mengakibatkan gangguan pertumbuhan janin dan juga meningkatkan risiko komplikasi ketika persalinan maupun pasca persalinan (Fauziah \& Sutejo, 2012).

Permasalahan gizi yang banyak terjadi pada ibu hamil antara lain Kekurangan Energi Kronik (KEK) dan anemia defisiensi besi. Wanita hamil sangat rentan terjadi anemia defisiensi besi karena pada kehamilan kebutuhan oksigen lebih tinggi sehingga memicu peningkatan produksi eritropoietin. Akibatnya, volume plasma bertambah dan sel darah merah (eritrosit) meningkat. Namun peningkatan volume plasma terjadi dalam proporsi yang lebih besar jika dibandingkan dengan peningkatan eritrosit sehingga penurunan konsentrasi hemoglobin $(\mathrm{Hb})$ akibat hemodilusi (Cunningham, 2013).

Pengaruh anemia dalam kehamilan dapat berakibat fatal jika tidak segera diatasi diantaranya dapat meningkatkan risiko kelahiran prematur, kematian ibu dan anak, serta penyakit infeksi. Anemia defisiensi besi pada ibu hamil dapat mempengaruhi pertumbuhan dan perkembangan janin atau bayi saat kehamilan maupun setelahnya. Selain itu, di negara berkembang banyak bayi berat lahir rendah (BBLR) dengan Intrauterin Growth Retardation (IUGR) karena ibu berstatus gizi buruk, anemia, malaria dan menderita penyakit menular seksual (PMS) sebelum konsepsi atau pada saat hamil (Dinkes, 2019).

Upaya pencegahan dan penanggulangan anemia dilaksanakan pemerintah melalui pemberian Suplementasi tablet besi dengan dosis pemberian sehari sebanyak 1 butir $(60 \mathrm{mg}$ zat besi dan 0,400 $\mathrm{mg}$ asam folat) berturutturut minimal 90 hari selama masa kehamilan. Program pemerintah yang telah dijalankan tersebut terlihat pada angka cakupan pemberian Tablet Tambah Darah (TTD) pada ibu hamil di Indonesia tahun 2018 berjumlah 81,16\%. Angka ini belum mencapai target Renstra tahun 2018 yang seharusnya berjumlah 95\% (Kemenkes, 2019).

Suplementasi tablet besi dianggap merupakan cara yang efektif karena kandungan besinya padat dan dilengkapi dengan asam folat yang sekaligus dapat mencegah dan menanggulangi anemia akibat kekurangan asam folat. Untuk menanggulangi masalah anemia, peningkatan asupan makanan dapat diupayakan dengan mengonsumsi bahan makanan yang mengandung zat gizi tinggi 
dan/atau meningkatkan absorpsi besi. dilakukan oleh Lathifah (2018), yang Bahan-bahan makanan yang kaya zat besi, diantaranya daging merah, unggas, hati, menyebutkan bahwa ada Pengaruh ikan, susu, yoghurt, buah-buahan dan sayuran berwarna hijau serta kacangkacangan (Ani, 2013).

Salah satu jenis kacang-kacangan yang mengandung zat besi tinggi adalah kacang hijau (Phaseolus Radiatus L). Kacang hijau sangat bermanfaat bagi kesehatan ibu hamil dan menyusui, juga untuk menunjang masa pertumbuhan anak. Kandungan zat besi dalam kacang hijau paling banyak terdapat pada embrio dan kulit bijinya, dengan kandungan zat besi pada kacang hijau sebanyak 6,7 mg per 100 gram kacang hijau (Astawan, 2011).

Kacang Hijau merupakan sumber makanan yang mengandung sumber protein, kaya serat, rendah karbohidrat, mengandung lemak sehat, kaya vitamin vitamin seperti vitamin B lain, seperti riboslavin, B6, asam pantothenat, serta niasin. Vitamin yang terkandung didalamnya membantu meningkatkan energi dan metabolisme tubuh dan mineral kaya enzim aktif. Berdasarkan penelitian Retnorini dkk (2017), Ada pengaruh pemberian tablet Fe dan Sari kacang hijau terhadap kadar hemoglobin pada ibu hamil (Retnorini, Widatiningsih , \& Masin, 2017). Hal ini didukung dengan penelitian yang Pemberian Kacang hijau Terhadap kenaikan kadar hemoglobin pada ibu hamil Trimester II di Wilayah Kerja Puskesmas Rawat Inap Way Kandis Bandar Lampung Tahun 2018 (Lathifah, 2018).

Studi pendahuluan yang dilakukan pada bulan Januari 2020 di Wilayah Kerja Puskesmas Nanti Agung Kabupaten Kepahiang, berdasarkan laporan bulanan jumlah ibu hamil dari Januari - Desember 2019 berjumlah 135 orang, terdapat 48 orang ibu hamil atau $(35,5 \%)$ mengalami anemia, angka tersebut lebih tinggi dalam periode yang sama tahun 2018 hanya berjumlah 13,55\%.

Penelitian ini bertujuan untuk mengetahui pengaruh pemberian Tablet $\mathrm{Fe}$ dengan penambahan Sari kacang hijau terhadap peningkatan kadar $\mathrm{Hb}$ pada ibu hamil TM III.

\section{METODE}

Penelitian ini menggunakan desain quasi eksperimen dengan pendekatan pre and post test control group design. Kelompok perlakuan pada penelitian ini adalah ibu hamil yang di berikan suplementasi tablet Fe penambahan sari kacang hijau satu kali sehari selama 7 hari, sedangkan kelompok kontrol adalah ibu hamil yang di berikan 
tablet Fe dengan dosis 1 kali sehari tanpa penambahan sari kacang hijau. Sebelum dan setelah intervensi baik pada kelompok eksperimen maupun kontrol dilakukan pengukuran kadar haemoglobinPopulasi penelitian adalah seluruh ibu hamil yang ada di Puskesmas Nanti Agung Kabupaten Kepahiang Propinsi Bengkulu Tahun 2019 dari bulan Januari-Desember berjumlah 135 ibu hamil. Pada penelitian ini menggunakan teknik pengambilan sampel secara simple random sampling. Kriteria inklusi dalam penelitian ini adalah a) ibu hamil trimester III, b) ibu hamil anemia ringan sebelum dan sesudah perlakuan, c) Ibu hamil yang bersedia menjadi responden. Kriteria eksklusi adalah a) Ibu hamil yang menderita penyakit kronis, b) Ibu hamil dengan KEK.

Peneliti membuat perhitungan besar sampel menggunakan rumus Freder. Berdasarkan perhitungan sampel, setiap kelompok terdapat minimal 16 sampel, dengan perkiraan drop out $10 \%$, untuk mengantisipasi kemungkinan drop out, sehingga sampel masing-masing kelompok 18 orang responden. Sehingga jumlah seluruh subjek penelitian sebanyak 36 orang responden.

Uji normalitas data menggunakan Shapiro wilk dan analisis menggunakan uji statistik nonparametrik yaitu dengan uji wilcoxon dengan tingkat kepercayaan $95 \%$ $(p \leq 0,05)$.

\section{HASIL DAN PEMBAHASAN}

Responden dalam penelitian ini adalah ibu hamil trimester III yang mengalami anemia ringan di Wilayah Kerja Puskesmas Nanti Agung Kabupaten Kepahiang berjumlah 36 orang. Karakteristik responden dalam penelitian dapat dilihat pada tabel berikut ini :

\section{Tabel .1 Karakteristik Responden}

\begin{tabular}{|c|c|c|c|c|}
\hline \multirow{3}{*}{ Karakteristik } & \multicolumn{4}{|c|}{ Kelompok } \\
\hline & \multicolumn{2}{|c|}{$\begin{array}{c}\text { Intervensi } \\
\quad(n=18)\end{array}$} & \multicolumn{2}{|c|}{$\begin{array}{c}\text { Kontrol } \\
(n=18)\end{array}$} \\
\hline & $\mathbf{N}$ & $\mathbf{F}$ & $\mathbf{N}$ & $\mathbf{F}$ \\
\hline \multicolumn{5}{|l|}{ Umur } \\
\hline 20-35 tahun & 16 & 88,9 & 18 & 100 \\
\hline$>35$ tahun & 2 & 11,1 & 0 & 0 \\
\hline Total & 18 & 100 & 18 & 100 \\
\hline \multicolumn{5}{|l|}{ Paritas } \\
\hline Primipara & 6 & 33,3 & 6 & 33,3 \\
\hline Multipara & 12 & 66,7 & 12 & 66,7 \\
\hline Grandemultipara & 0 & 0,0 & 0 & 0,0 \\
\hline Total & 18 & 100 & 18 & 100 \\
\hline
\end{tabular}

Tabel 1 menunjukan bahwa berdasarkan karakteristik umur responden dengan usia kehamilan trimester III pada kelompok intervensi hampir seluruhnya atau sebanyak 16 orang $(88,9 \%)$ dengan rentang umur 20-35 tahun, sedangkan pada kelompok kontrol seluruh responden atau sebanyak 18 orang (100\%) adalah responden dengan rentang umur 20-35 tahun. Berdasarkan paritas pada kelompok intervensi, hampir seluruh responden atau sebanyak 12 orang $(66,7 \%)$ adalah ibu 
hamil dengan paritas multipara, sedangkan pada kelompok kontrol sebagian besar responden atau sebanyak 12 orang $(66,7 \%)$ adalah ibu hamil dengan paritas multipara.

Tabel. 2 Perbedaan Kadar Hb Sebelum dan Setelah Intervensi

\begin{tabular}{|c|c|c|c|c|}
\hline Variabel & Mean & Median & SD & $p$-value ${ }^{a}$ \\
\hline \multicolumn{5}{|l|}{$\begin{array}{l}\text { Kelompok } \\
\text { Intervensi }\end{array}$} \\
\hline Pre test & 10.60 & 10.7 & 0.36 & \multirow{2}{*}{$0.000^{*}$} \\
\hline Post test & 12.15 & 12.15 & 0.78 & \\
\hline \multicolumn{5}{|l|}{$\begin{array}{l}\text { Kelompok } \\
\text { Kontrol }\end{array}$} \\
\hline Pre test & 10.45 & 10.50 & 0.35 & \multirow{2}{*}{$0.000^{*}$} \\
\hline Post test & 11.04 & 10.90 & 0.58 & \\
\hline
\end{tabular}

Berdasarkan tabel 3, pada kelompok intervensi diperoleh rata-rata kadar hemoglobin sebelum pemberian tablet Fe dengan penambahan sari kacang hijau sebesar $10.6 \pm 0.36 \mathrm{~g} / \mathrm{dl}$ dan rata-rata kadar hemoglobin setelah pemberian pemberian perlakuan pada kelompok intervensi sebesar $12.150 \pm 0,78 \mathrm{~g} / \mathrm{dl}$. Rata-rata peningkatan kadar $\mathrm{Hb} 1,55 \pm 0.43 \mathrm{~g} / \mathrm{dl}$. Sementara pada kelompok kontrol, diperoleh rata-rata kadar hemoglobin sebelum pemberian tablet $\mathrm{Fe}$ tanpa penambahan sari kacang hijau sebesar $10.45 \pm 0.35 \mathrm{~g} / \mathrm{dl}$ dan rata-rata kadar hemoglobin setelah pemberian tablet $\mathrm{Fe}$ sebesar $11.04 \pm \quad 0,23 \mathrm{~g} / \mathrm{dl} . \quad$ Terjadi peningkatan rata-rata kadar $\mathrm{Hb}$ sebesar $0,58 \pm 0.23 \mathrm{~g} / \mathrm{dl}$.

Hasil analisis pada kelompok intervensi dengan menggunakan uji wilcoxon diperoleh nilai $\mathrm{p}=0.000<0,005$ yang artinya ada perbedaan antara kadar $\mathrm{Hb}$ sebelum dan setelah intervensi pemberian tablet Fe dengan kombinasi sari kacang hijau. Sementara hasil analisis pada kelompok kontrol dengan menggunakan uji wilcoxon diperoleh nilai $\mathrm{p}=0.000<0,005$ yang artinya ada perbedaan antara kadar $\mathrm{Hb}$ sebelum dan setelah intervensi pemberian tablet $\mathrm{Fe}$, sehingga Ha diterima dan ada pengaruh pemberian suplementasi $\mathrm{Fe}$ dengan penambahan Sari Kacang Hijau dalam peningkatan kadar $\mathrm{Hb}$ pada ibu hamil di Wilayah Kerja Puskesmas Nanti Agung Kabupaten Kepahiang Tahun 2019 Provinsi Bengkulu.

Hasil penelitian menunjukkan adanya peningkatan kadar $\mathrm{Hb}$ baik pada responden yang diberikan tablet Fe dengan dosis 1 kali sehari selama 7 hari tanpa dengan menambahkan sari kacang hijau, dengan kenaikan rata-rata sebesar $0,58 \mathrm{gr} / \mathrm{dl}$ ataupun pada responden yang juga diberikan tablet Fe dengan dosis yang sama akan tetapi dengan menambahkan sari kacang hijau sebanyak 500 cc yang diminum 2 kali (pagi dan sore) dengan ratarata kenaikan dalam 7 hari sebesar 1,55 gr/dl. Peningkatan rata-rata kadar $\mathrm{Hb}$ ini lebih tinggi pada responden dengan perlakuan menambahkan sari kacang hijau dibandingkan dengan pemberian hanya 
tablet $\mathrm{Fe}$, dengan selisih rata-rata peningkatan kadar $\mathrm{Hb}$ sebesar 0,59 gr/dl.

Peningkatan kadar hemoglobin pada responden berbeda-beda antara responden satu dengan yang lainnya hal ini disebabkan karena adanya perbedaan penyerapan besi oleh tubuh. Menurut Ani (2013) Penyerapan besi jenis non-heme sangat dipengaruhi oleh zat pengikat yang dapat menghambat ataupun memacu penyerapan. Penyerapan besi non-heme lebih rendah karena adanya pengaruh zat-zat yang mempertahankan besi tetap dalam keadaan larut. Zat penghambat ini membentuk komplek yang mengalami presipitasi sehingga besi sulit diserap (Ani, 2013).

Anemia pada kehamilan yang disebabkan kekurangan zat besi mencapai kurang lebih 95\%. Terjadinya peningkatan volume darah mengakibatkan hemodilusi atau pengenceran darah sehingga kadar $\mathrm{Hb}$ mengalami penurunan dan terjadi anemia. Pengenceran darah dianggap sebagai penyesuaian diri secara fisiologis dalam kehamilan dan bermanfaat bagi wanita. Pertama - tama pengenceran itu meringankan beban jantung yang harus bekerja lebih berat dalam masa hamil, karena sebagai akibat hidremia cardiac outputmeningkat (Varney, 2012).

Salah satu cara mengatasi anemia dalam adalah konsumsi bahan-bahan pangan sumber zat besi, diantaranya daging, hati, ikan, susu, yoghurt, kacangkacangan, sertasayuran berwarna hijau .Selain itu pola dan ragam nutrisi ibu hamil yang didapatkan dari makanan yang mereka makan setiap harinya, dimana setiap ibu mengkonsumsi makanan yang berbedabeda setiap harinya sehingga kenaikan kadar hemoglobin yang lebih tinggi selain didapatkan dari kacang hijau dan tablet zat besi yang ibu konsusmsi setiap hari tetapi disebabkan juga oleh absobsi dari makanan lain.

Sayur-sayuran berprotein tinggi seperti buncis dan kacang-kacangan. Salah satu jenis kacang-kacangan yang mengandung zat besi tinggi adalah kacang hijau (vignaradiata). Kacang hijau sangat bermanfaat bagi kesehatan ibu hamil dan menyusui,juga untuk menunjang masa pertumbuhan anak.Kandungan zat besi dalam kacang hijau paling banyak terdapat pada embrio dan kulit bijinya. dengan jumlah kandungan zat besi pada kacang hijau sebanyak 6,7 mg per100 gram kacang hijau dan salah satu bentuk penyajian kacang hijau yang paling efektif adalah dengan sari kacang hijau,yaitu air dan ampasnya disaring dan dipisahkan sehingga minuman tersebut padat gizi (Retnorini, Widatiningsih , \& Masin, 2017).

Kacang hijau selain memiliki 
kandungan zat besi, vitamin c, dan zat seng yang berperan dalam penanganan anemia defisiensi besi. Kacang hijau juga mengandung vitamin A sebesar $7 \mathrm{mcg}$ dalam setengah cangkirnya. Kekurangan vitamin A dapat meperburuk anemia defisiensi besi. Pemberian suplementasi vitamin A memiliki efek menguntungkan pada anemia defisiensi besi. Vitamin A memiliki banyak peran di dalam tubuh, antara lain untuk pertumbuhan dan diferensiasi sel progenitoreritrosit, imunitas tubuh terhadap infeksi dan mobilisasi cadangan zat besi seluruh jaringan. Interaksi vitamin A dengan zat besi bersifat sinergis. Berdasarkan jumlahnya, protein merupakan penyusunan utama kedua setelah karbohidrat. Kacang hijau mengandung $20-25 \%$ protein. Protein pada kacang hijau mentah memiliki daya cerna sekitar $77 \%$. Daya cerna yang tidak terlalu tinggi tersebut disebabkan oleh adanya zat antigizi, seperti anti tripsin dan tanin (polifenol). Untuk meningkatkan daya cerna protein tersebut, kacang hijau harus diolah terlebih dahulu melalui proses pemasakan, seperti perebusan, pengukusan, dan sangria (Astawan, 2011).

Kandungan protein, karbohidrat, dan lemak pada kacang hijau mendukung proses sintesis hemoglobin. Karbohidrat dan lemak membentuk suksinil-KoA yang selanjutnya bersama glisin akan membentuk protoporfirin melalui serangkaian proses porifirinogen. Protofirin yang terbentuk selanjutnya bersama molekul heme dan protein globin membentuk hemoglobin. Kandungan glisin 0,9\% dari 22\% jumlah asam amino total pada kacang hijau, sehingga kacang hijau selain mampu membantu sintesis heme dalam hal zat besi juga mampu membantu sintesis heme sebagai bahan pembentuk sintesis heme. Bovel 1Benjamin menyatakan bahwa absorbsi besi dapat meningkat 4 kali lipat dengan pemberian glisin. Penelitian tersebut dengan menggunakan preparat iron bis-glycine yaitu senyawa besi-glisin kuat yang dapat menghasilkan konfigurasi cincin heterosiklik ganda. Bentuk ini dipercaya dapat melindungi besi dari faktor penghambat besi dan berbagai interaksi di usus halus. Glisin juga turut membentuk antioksidan glutation yang dapat mempertahankan besi diet dalam bentuk fero, sehingga absorbsi besi dapat ditingkatkan. Proses penyerapan besi juga membutuhkan vitamin dapat mempertahankan besi diet dalam bentuk fero, sehingga absorbsi besi dapat ditingkatkan. Proses penyerapan besi juga membutuhkan vitamin $\mathrm{C}$, vitamin $\mathrm{C}$ membantu dalam proses absorbsi besi dan membantu melepaskan besi dari tempat 
penyimpanannya. Vitamin $\mathrm{C}$ dapat berperan meningkatkan absorbsi zat besi non heme menjadi 4 kali lipat. Vitamin $\mathrm{C}$ dan zat besi membentuk senyawa askorbat besi kompleks yang mudah larut dan mudah diabsorbsi (Miyata, 2010).

Vitamin C diperlukan oleh tubuh untuk proses penyerapan besi. Salah satu kandungan dalam kacang hijau yaitu vitamin C. Vitamin C membantu dalam proses absorbsi besi dan membantu melepaskan besi dari tempat penyimpanannya. Vitamin $\mathrm{C}$ dapat berperan meningkatkan absorbsi zat besi non heme menjadi 4 kali lipat. Vitamin $\mathrm{C}$ dan zat besi membentuk senyawa askorbat besi kompleks yang mudah larut dan mudah diabsorbsi. Penelitian menunjukkan ada hubungan yang bermakna antara peningkatan kadar $\mathrm{Hb}$ dengan konsumsi vitamin $\mathrm{C}$, zat besi non heme akan meningkat $2-20 \%$ bila mengkonsumsi vitamin C. Mengkonsumsi 2 cangkir kacang hijau dalam setiap hari berarti telah mengkonsumsi $80 \%$ kebutuhan vitamin C dalam setiap hari yaitu $75 \mathrm{mg}$ (Maulina \& Sitepu, 2015).

Hasil penelitian sejalan dengan penelitian Lathifah (2018) yang menunjukan bahwa ada pengaruh pemberian kacang hijau terhadap kenaikan kadar hemoglobin pada ibu hamil trimester
II. Hasil penelitian ini didukung oleh Amalia (2016), menunjukkan bahwa ratarata kadar hemoglobin $(\mathrm{Hb})$ 9,6 gr/dl atau mengalami anemia ringan sebelum pemberian minuman kacang hijau, dan ratarata kadar hemoglobin $(\mathrm{Hb})$ 10,6 gr/dl atau tidak anemia setelah pemberian minuman kacang hijau. Ada pengaruh pemberian minuman kacang hijau terhadap peningkatan kadar hemoglobin $(\mathrm{Hb})$ dengan $\mathrm{p}=0,000$ (Lathifah, 2018).

Minuman sari kacang hijau dapat meningkatkan kadar hemoglobin dalam darah secara signifikan karena mengandung zat besi, vitamin c, dan zat seng dan vitamin A memiliki banyak peran di dalam tubuh, antara lain untuk pertumbuhan dan diferensiasi sel progenitoreritrosit, imunitas tubuh terhadap infeksi dan mobilisasi cadangan zat besi seluruh jaringan. Minuman kacang hijau dianjurkan untuk dikonsumsi ibu hamil sebagai usaha preventif/ pencegahan anemia pada ibu hamil. Penelitian ini memiliki keterbatan dalam jumlah sampel yang kecil sehingga diharapkan penelitian dalam jumlah sampel yang lebih besar dan metode penelitian yang berbeda.

\section{SIMPULAN}

Hasil penelitian menyimpulkan bahwa terdapat pengaruh pemberian Tablet $\mathrm{Fe}$ dengan penambahan sari kacang hijau 
terhadap peningkatan kadar $\mathrm{Hb}$ pada ibu hamil Trimester III.

\section{DAFTAR PUSTAKA}

Ani, L. S. (2013). Anemia Defisiensi Besi Masa Pra Hamil \& Hamil. Jakarta: EGC.

Astawan, M. (2011). Sehat Dengan Hidangan Kacang Dan Biji-bijian. Bogor: Swadaya.

Cunningham, F. G. (2013). Obstetri Wiliam Edisi 23. Jakarta: EGC.

Dinkes. (2019). Profil Kesehatan Kabupaten Kepahiang Tahun 2018. Kepahiang: Dinkes Kepahiang.

Fauziah, S., \& Sutejo. (2012). Keperawatan Maternitas Kehamilan. Jakarta: Kencana Prenada Media.

IBRD. (2019, Juni 11). The Wold Bank. Retrieved 1 1, 2020, from World Development Indicators: https://www.worldbank.org/

Kemenkes. (2019). Laporan Nasional RISKESDAS 2018. Jakarta: Kemenkes RI.

Lathifah, N. S. (2018). Pengaruh Pemberian Kacang Hijau Terhadap Kenaikan Kadar Hemoglobin pada Ibu Hamil Trimester II di wilayah kerja Puskesmas Rawat Inap Way Kandis Bandar Lampung tahun 2018. Jurnal Kebidanan, 4(3), 139-144.

Maulina, N., \& Sitepu, I. P. (2015). Pengaruh Pemberian Kacang Hijau (Phaseolus radiatus) Terhadap Peningkatan Kadar Hemoglobin Tikus Putih (Rattus norvegicus) Jantan Galur Wistar. JPKim, 57-60.

Miyata, S. M. (2010). Nutrisi Janin dan Ibu Hamil Cara Membuat Otak Janin Cerdas. Yogyakarta: Mulia Medika.
Retnorini, D. L., Widatiningsih , S., \& Masin. (2017). Pengaruh pemberian tablet fe dan sari kacang hijau terhadap kadar hemoglobin pada ibu hamil. Jurnal Kebidanan, 8-16.

Varney, H. (2012). Buku Ajar Asuhan Kebidanan. Jakarta: EGC. 